\title{
Forum
}

\section{Citizenship and Old Age: The End of the Road?}

\author{
PAUL HIGGS*
}

\section{ABSTRACT}

This paper is concerned with the interlinked issues of citizenship and the structured dependency of older people within Social Gerontology. It argues that implicit in much British Social Gerontology is a strategy of advancing the wellbeing of elderly people through the extension of citizenship rights. Absence of these rights leads to poverty, exclusion and ageism being commonplace experiences of large sections of the older population. This approach draws heavily on the ideas regarding social citizenship of $T$. $H$. Marshall who has influenced much mainstream social policy in Britain since 1945 . Changes to the Welfare State since r979 have seriously questioned the validity of this approach and many of these criticisms apply to the structured dependency approach. Recent work on citizenship can help us to see how the relationship between old age and citizenship has changed and how far theory in social gerontology needs to change to take account of these new circumstances.

KEY WORDS - Citizenship, social gerontology, social theory.

\section{Introduction}

That older people are treated differently from other groups in society is one of the baselines of social gerontology. That they should not be is one of the tenets that flows from this understanding. As a consequence

* Department of Psychiatry, University College London Medical School, Wolfson Building, Riding House Street, London $\mathrm{W}_{\mathrm{I}} \mathrm{N}$ 8AA. 


\section{$53^{6}$ Paul Higgs}

much research is conducted into how social processes affect older people in a negative fashion. At one level much work is done on how old age is pathologised as a process of infirmity and illness when the opposite is true for most older people (Walker and Phillipson, I986; Henwood, 1992). In a similar fashion it has been argued that the organisation of social policy often has the direct effect of creating social dependency in older people (Townsend, 198I). This can be through pensions policy, discrimination in health policy and through the infantilisation of older people's actions. However, what it all adds up to is ageism.

Structured dependency theory has been the most widespread and consistent approach to identifying and suggesting remedies to ageism. It has an implicit political strategy of advocating full citizenship rights for older people because it is these social rights that underpin many of welfare democracies of western Europe, and it is these rights that older people are being denied through discrimination.

This paper argues that while the theoretical thrust of the structured dependency argument has been broadly correct, these ideas need to be re-examined in the light of a changing social and political reality. Particularly problematic is the concept of citizenship itself which has moved from being an embodiment of universal social rights to a much more narrow conception very different from the ideas of $\mathrm{T} . \mathrm{H}$. Marshall (1992). This shift is in part the product of changes in the social structure which have led individuals to stress their difference from one another rather than their identity.

It is the contention of this paper that because of the erosion of a previously existing 'mass society', citizenship in its older form can no longer exist. While social stratification is still a consequence of social structures (Marshall et al. 1988) the ways in which individuals and families live out their lives is more concerned with the cultures of consumption and lifestyle (Bocock, I993). This creates a more individualised population who respond to social policy in part as consumers.

Current government policy recognises and encourages this new state of affairs and, abandoning the welfarist principles of social rights and universalism, attempts to reconstruct the citizen along the lines of a market-orientated individual. In a parallel move the increase in the information-gathering capacities of the modern state suggests that this does not simply represent a movement back to i gth century laissez faire social policies. Instead, social policy is increasingly based on surveillance and individuation. A state of affairs which results in more intervention in the lives of citizens and correspondingly less public 
control. This paper concludes that the idea of citizenship as a way of increasing the power of older people over their lives is misjudged given that the circumstances that made such an idea a realistic possibility no longer exist.

\section{Structured dependency and citizenship}

Social Gerontology has made strenuous efforts to separate the idea of old age from the processes of ill health and physical frailty. The reality that the majority of retired people are in relatively good health is emphasised, as is the fact that very few older people are in any form of institutional care (Henwood, I 992). Concentrating on these aspects of older people's lives allows Social Gerontology to stress the similarities that exist across the generations and challenge the cultural assumptions of generational discontinuity (Arber and Evandrou, 1993). In claiming that older people are not an homogenous group linked together by a common physical frailty, and that retired people are as diverse as the rest of the population, scope is provided for the idea of the third age - a stage of life beyond the concerns of childhood/adolescence and of parenthood. However, the potential to benefit from this lifestage is dependent upon sufficient resources being available both to individuals and to institutions. That a greater proportion of older people are in poverty than is the case among the rest of the population creates a situation where the full opportunities of this third age cannot be enjoyed by many who reach retirement. A major factor in bringing about this state of affairs is the low level of the state retirement pension which provides pensioners with only a small proportion of the average wage (Townsend, I98I). Structured dependency of older people results from a lack of resources which in turn prevents participation in society. Lack of participation in society leads to the exclusion and marginalisation of older people. Marginalisation leads to low-status and lowesteem being accorded to older people and this leads to discrimination.

Many social gerontologists who subscribe to the structured dependency thesis explicitly believe that the 'ageism' that results is wrong because it creates inequality and denies some members of society the right to participate fully as citizens. For this reason alone ageism must be challenged and overcome by social policies (Leonard, I982; Midwinter, I992). Central to doing this is the extension of citizenship rights to older people so that the simple fact of exclusion from the wage economy does not lead older people into an inferior social category 


\section{$53^{8}$ Paul Higgs}

(Phillipson, 1982). Such rights can be varied in scope from anti-age discriminatory legislation to the creation of political structures. However, a number of influential social gerontologists have prioritised the need for a radical reworking of pensions policy if greater equality is to be created. In a 'Manifesto for Old Age' Bornat et al. propose that the "retirement pension needs to be greatly increased, to a level which provides a "participation standard" of living for all pensioners. This would probably be higher than the pensioner movement's current goal of one-third the average wage for a single person' (Bornat et al. 1985, pp 78-79). In this way one of the fundamental social rights of citizenship would be established.

Creating the basis for an active participation in society through financial means also provides the basis for a reordering of the relationship between older people and health. The stereotyping of old age as infirmity would be challenged as active older people become visible in society. Where physical infirmity or chronic illness did arise older people would be able to utilise their position within the community to make decisions about what older people themselves wanted. All in all what many different writers are describing is the full integration of older people into society rather than an acceptance of their disengagement or separateness; a position adopted by an earlier (American) tradition. Integrating old age into a concept of a life course shared by all humans does not only benefit older people but also those of different generations. As Arber and Ginn (I99I) have argued much feminist research has concentrated on the gendered nature of informal care of older people. On occasion this focus has seemingly produced a division of interest between younger women carers and the older people being cared for. One strand of the manifesto advocated by Bornat $e t$ al. attempts to minimise these conflicts through the creation and funding of formalised caring options and support.

An irony of the citizenship approach is that in trying to overcome structured dependency many of the proposals end up homogenising all older people into an undifferentiated group who need to be made equal. Recognising that structural inequalities in old age are often the effects of social differences created at earlier points in the lifecourse leads the authors of 'A Manifesto for Old Age' to advocate the limiting of certain privileges associated with occupational pensions. A similar effect is produced by many of the studies examining income differences in old age. The poverty of large proportions of older people is identified to the detriment of those sections of the older population who are not in poverty. Even when it is acknowledged that this group exists and is likely to increase in the future the full implications are not considered 
(Wilson, 1993). This is not to argue that pointing out the poverty of many older people is not important or that they don't matter; rather it establishes the point that approaches based on structured dependency theory are almost obliged to adopt a welfarist approach to old age. That there are limitations to this view can be gleaned from both the fact that Government social policy seems not to be interested in overcoming structured dependency and that there is little public interest in them doing so. Another significant problem is that the approach has difficulties dealing with the realities of older people who see old age from the perspective of lifestyle. These 'third agers' seem to give the lie to many of the tenets of structured dependency by constructing old age as a process of leisure (Featherstone and Hepworth, I 986 ). Though possibly limited in numbers, it is likely that succeeding generations of older people are more likely to see themselves from this perspective - rather than as old age trade unionists. The problems faced by the advocates of old age citizenship outlined above are the same problems as those faced by Marshall and those influenced by him, an approach which has underpinned much orthodox British social policy since the second world war. It is to this perspective we now turn.

\section{Citizenship and the welfare state}

The ideal of the welfare state which seemed unassailable for much of the latter part of the twentieth century now seems an anachronism representative of a cheerfully departed past. Current government social policy now reverberates with terms such as 'dependency culture' and 'nanny state' and seeks to place personal responsibility at the heart of all programmes. The role of the citizen in all of this is to be the civicminded family member who pays his or her taxes, obeys and respects the law, and who knows who to complain to if public bodies fail to honour their contractual obligations.

Citizenship in this reduced sense seems little more than the actions of individual (or family-orientated) social consumers concerned with process and outcome but very little else. Structural questions regarding the politics and philosophy of the nation are absent. Instead of egalitarianism there is equality of opportunity and instead of social security there are loans and the targeting of benefits. All told, the elimination of traffic cones seems to be as important to the Government as the elimination of poverty. 
This is all a long way from the model of citizenship outlined by T. H. Marshall in I950 (Marshall, 1992) where the emphasis was on community and belonging. It was an optimistic formulation embodying the idea of the historical progression of freedom. This had been granted first in its economic and legalistic form during the I8th century, then in its political form through the vote during the 19th and 2oth centuries, and lastly through the social rights of the post-1945 welfare state. That post-war Britain represented the triumph of social development was taken as read (Titmuss, 1974). The inequalities created through the industrial revolution and the market were to be contained by the state for the purpose of social harmony. Citizens were to have a stake in society, one which removed the desire radically to change the institutional order or challenge the centrality of the market.

To the 'new right' who came into prominence in the 1970 s and ig8os these principles were seen as anathema. The compromise of corporatism was worse than a straightforward abandonment of belief in freedom and the market. The rights of citizenship led to bureaucracy, inefficiency and the power of the state over all individuals. Furthermore it led to economic stagnation and decline as the leviathan of the expanding public purse crushed all initiative through taxation and regulation (Kymlicka and Norman, 1994).

The recodification of citizenship during the 1980 owes more than a little to the concepts of justice and freedom advocated by Heyek and intergrated with the economic writings of Milton Friedman (Gamble, 1986). The most important conclusion drawn by those influenced by this synthesis was that it was wrong to promote social justice by any other means than the invisible hand of market action. Incorporated into government practice this has severely questioned the utility of what has been described as the Keynesian Welfare state based as it was on state interventionism. The ideals of equality and of participation have been replaced by competitiveness and deregulation.

The reasons for this historical trajectory have been hotly debated (Taylor-Gooby, I991 $a$ ) but, while the welfare state may still be in existence, its centrality to the privileges of citizenship is no more. Attachment to the principles of the welfare state may still command widespread public support (Taylor-Gooby, I99 I $b$ ), but the practices of the various components no longer work on the assumption that they are providing their services to an undifferentiated citizenry. Instead, most public services regard themselves (or are expected to regard themselves) as competing in whatever market that has been chosen for them. The practicalities of each individual service are different but it is no longer 
just those receiving stigmatised benefits or services who are treated as if they have failed to make adequate personal provision. To be reliant on the public sector in any area is a ready acceptance of having to make do with what the public purse is prepared to offer on a timescale that necessarily matches. Comparisons and league tables are offered as a way of compensation but the clear implication is that if you want something - you should make your own provision for it.

This is not to say that this process is unproblematic, rather, that the pragmatism of the public will allow them to recognise these new circumstances as natural and in accordance with their own new circumstances. Attachment to the ideals of collectivism may still be a feature of public opinion, but the areas where it finds popular support have become narrowed to institutions such as the NHS, and even there the level of satisfaction is low (Taylor-Gooby, $199 \mathrm{I} b$ ).

The heyday of citizenship occurred at a time when the majority of the population was clearly stratified into defined occupational groups whose interests could be defined in terms of mass society (Cronin, I 984). In such societies class interests could be defined and could be appealed to. Marshall's idea of social equality responded to such a world offering mass benefits and mass entitlements. The vision was successful but the reality not always so. As with nationalisation the social effectiveness of the Keynesian welfare state did not always live up to its potential. Class inequalities remained and those who received maximum benefit from the new structures were often the middle class both through employment and through increased opportunity (Le Grand, I982).

More significantly, at the point during the I97os when economic recession made the claims of citizenship practical, what was on offer was dramatically reduced. Instead of offering a safety net against the degrading effects of market instability, the welfare state was used as a structure of labour discipline (Gough, 1984). The benefits in kind that made up the social wage were also reduced and indeed blamed for the poor state the economy was in in the first place (Taylor-Gooby, 199 I $a$ ).

These new circumstances made belief in the ideal of citizenship difficult particularly as they were accompanied by successive incomes policies which cut deeply into the living standards of the then still relatively cohesively organised working class (Kavanagh, I 986).

Nineteen hundred and seventy nine is seen as a water-shed in postwar British politics because of the election to government of Margaret Thatcher and the ensuing policy turnaround. Of equal significance are some of the reasons why her party won, the low-paid public-sector workers' revolt against pay policy, for example, and the promise to 
restore 'free collective bargaining' to skilled groups of workers. If the I 970 s were the high point of trade union corporatism, they were also the last point in which the politics of mass society were to be allowed to play a role. Studies of voting behaviour increasingly identified the pragmatic voter who responded to inducements and whose concerns were heavily parochial (Franklin, I986).

Obviously, this process is only part of the problem for the continuing relevance of citizenship. Not every group and not every individual was considered or treated as an equal. The very eligibility of individuals for the rights of citizenship depended upon who they were and how much influence they had to wield. The position of women is a particular case in point where the rights of citizenship were tied strongly to the duties that they were expected to carry out (Lister, 1990). Equality of outcome was not one of the features of the welfare state.

Reeling under these blows supporters of the Marshallian idea of citizenship have accepted that there was much wrong with the welfare state especially in its lack of respect for individuals and its concentration on 'statist' solutions or in its reliance on corporatism (Ferris, 1985; Plant, 1988). Reformulations have either taken on a 'civil society' approach concentrating on the plurality of organisations that citizens can participate in or be catered for by, or they have concentrated on the ethic of altruism that needs to be fostered. That there is little that distinguishes these positions from developing Conservative social policies is apparent. For civil society read market and for individual freedom read non-intervention.

\section{The state, status and citizenship}

An alternative view of citizenship has been developed by Bryan Turner (1988; I989; 1990). Acknowledging that Marshall's approach was culturally bound to the shores of Britain and that it was unproblematically teleological, Turner counters that citizenship is intrinsically bound up in the nature of modern society. As the highly stratified social structures of western industrialised capitalism give way to the more fragmented forms of consumer society, so the importance of status increases (1988, p. 43-78). Status has the power to include or exclude individuals from a community or society. So does citizenship. In this way citizenship is a form of status which is based upon being a full member of a modern nation-state. At its most conventional Turner is adopting Parsons' ideas regarding the civil rights struggles in America. 
For Black people in the USA their exclusion from the 'public sphere' indicated, if not created, a lack of status and therefore of power. To be a citizen and to be accepted as one is therefore extremely important in the social construction of groups.

Turner goes further and argues that as traditional occupational structures play less and less of a role in most people's day-to-day activities a multitude of lifestyle choices come to replace them. Status politics based on group identities become crucial as the practicalities of policy formation and implementation in the public sphere. Obviously this argument owes more than a little bit to Max Weber. The crucial difference is that much of the politics of status groups is played out in the realm of the welfare state or in the grey area of the state-assisted voluntary organisation. To extend Turner's argument, it would seem that the collapse of the dominance of class in society could be reflected in the rejection of mass provision of welfare. This does not kill off the idea of citizenship because status groups primarily want their particular needs met and may be unconcerned as to how they are. It could be further argued that a more flexible welfare environment would be more responsive to them than powerful welfare bureaucracies. Special interest perspectives and budgetary control over resources might go a long way in weakening the hold of a universalistic, public sector dominated, mass welfare system.

Older people are, according to Turner, in competition with other social groups because the negative experience of ageing results in them being denied their universalistic rights of citizenship. This leads Turner to describe them as a 'state administered status group' because they become the clients of the state in order for their social entitlements to be enforced (Turner, 1989, p. 592). Turner clearly sees the possibility of the development of a politics of old age in the mould of the US 'Grey Panthers' because, he argues, 'competitive struggle between social groups over resources [is] the essential feature of a sociology of status' (Turner, 1989, p. 593). Such competition has the effect of creating social solidarity and identity within the group. The consequence of this, according to Turner, is not a threat to social cohesion but rather an extension of social membership, as conflict provides a way in which enhanced social mobility will be possible, at least in principle. As he writes:

My view of status conflicts is in this limited sense 'positive', since I treat this competitive struggle as a process which brings about various forms of social solidarity and group membership. Social welfare rights as a consequence of political struggle are also mechanisms for the integration of oppositional and marginal groups within the political community. Inflationary wage spirals 


\section{Paul Higgs}

may be unintentionally a safety valve against more violent forms of political protest (Turner, 1989, p. 593).

Running through Turner's argument is the notion of active citizenship which can only take shape in relation to the nature of the state. Marshall's argument is criticised for not having a clear theory of the state. This is important because, following Mann (1987), the policies adopted by a state dictate the form citizenship will take. Mann outlines five differing ruling class strategies (liberal, reformist, authoritarian monarchist, fascist, and authoritarian socialist). All of them involve deliberate attempts to deal with modernity and industrialisation, and most significantly the political threat represented by the working class. A consequence of this is whether or not citizens are active or passive and whether the individual's concerns are strictly private or whether they can be addressed in the public realm. Certain formations allow for the development of an active citizenary such as revolutionary French tradition and some don't such as the German experience of Fascism. The public sphere is either open as in Britain or closed as in the USA.

Taking this extension of Turner's argument it would seem that if the concept of citizenship and old age is to mean anything it has to be based on both a notion of public activism and a public sphere in which to act. These two conditions seem to be questionable, at least in current circumstances. A further problem is the fact that older citizens, active or not, are presented as one of the causes of social crisis through their disproportionate demands for welfare resources (Thomson, I989). Such intergenerational conflicts lead, at least in principle, to more than just interest-group competition.

\section{Citizenship as surveillance}

Given the dilemmas about the viability of the idea of citizenship it may be more realistic to express the concept as being composed of a number of procedural rights for individuals and drop the foundation of collective or mass substantive rights. Present social policy in Britain seems to be going in this direction. The 'Citizen's Charter' is an ideal building on various specific charters in health, railways and government. Citizenship in this form is a relationship between the state and the individual. The citizen can expect to be treated in certain ways and can reasonably expect specified levels of service. Treatment that does not meet with these standards can be complained about and compensation secured. 
Implicit in this model is the idea of contract. This cornerstone of civil law is not only applied positively to members of the public dealing with large public and private sector organisations but also negatively to those receiving welfare benefits. For example, unemployed people seeking the 'jobseeker's allowance' now make a formal contract to undertake certain jobseeking activities such as regularly going to a jobcentre or applying for a specified number of jobs every week. The idea of entitlement as conceived by Marshall has been replaced by a 'bourgeois' concept of contract. The use of the Social Fund exemplifies this approach where ability to pay back a 'loan' is the primary criterion for entitlement.

Contracts are also expected to dominate at an institutional level. Health Authorities are expected to purchase an appropriate range of health services on behalf of individuals in their local populations; that is if fundholding GP practices aren't already doing so. Likewise Social Services departments are expected to set contracts for individually tailored packages of community care. In both of these cases the individual has his/her needs assessed and met by organisations acting on their behalf. Rights and obligations are also invested by individuals in these organisations against whom complaints can be taken out and expectations made.

As can be seen individuation is the starting point of this new reworking of the idea of citizenship. As such it reflects aspects that have always been present in civil society; the importance of contract; equality of treatment; freedom of choice etc (Green, I 993). It would be a mistake, however, to view these changes as simply the return to the 'laissez faire' social policies of the Victorian era. Rather than it being a retreat from the welfare state it is a retreat from the idea of mass welfare. If the ideas of universalism have been rejected by policy makers as irrelevant for an increasingly fragmented society, so too has the notion of a community of interest existing between all members of society. The general public may be ambivalent on the implications of this for a number of key institutions such as the NHS and education but there is no mass response to them (Taylor-Gooby, 1992 $b$ ). This is partly because the mass bodies that could organise such a response no longer have such a key-defining role in the consciousness of the population. The culture of the mass working class, of trade unionism and the Labour Party, in many parts of the UK no longer exists to any extent (Cronin, I984). Of equal importance are factors connected to the nature of the lives that most people live. The prevalence of consumption as a way of creating and maintaining lifestyle has been noted by Turner (1988) and supported by many others (Bocock, I993). 


\section{Paul Higgs}

At one level this seems to be restating the truisms of civil society; that real life exists in the buying and selling of commodities. Labour power is treated as an unproblematic commodity by all sides (Marx, 1976).

Of more importance is the notion of the abstract individual that exists in civil society and which modern social policy places at its centre (Foucault, 1979). The model citizen is a composite of modern norms and values against which real ones are measured. The model citizen is usually male, employed, in a stable two-parent household, does not commit crime and, if a mother, sees her priority as looking after children. Deviations from this pattern are then the appropriate subject of social policy which is how to get individuals back to conforming to this model or if this fails, or is impossible, how to exclude and control the particular deviant group. This process does not just exist at a cultural level or indeed just for adults, it also relates to education, health and disability (Hewitt, 1992). Children are now routinely monitored through national testing, through the health services and through the welfare services. In each of these areas expert-derived concepts of normality or appropriateness are utilised and those individuals causing concern by not meeting them are given special attention. This is not to argue that what is noted has no value or is done with the wrong intentions, but rather that it sees the individual as a version of the normal however that is defined.

In his account of citizenship Anthony Giddens (1985) argues that these processes are not arbitrary. Surveillance of the population is central to the activities of the modern nation state given that with larger populations direct repressive power is more and more difficult to organise. Giddens' development of the work of Michel Foucault is acknowledged. Even more relevant is Foucault's idea of 'governmentality' (Foucault, I99I) which can be extended to inform the current debates about citizenship and older people. This concept refers to the ordering of populations around particular ideas or discourses with the object of administering them. Again, the process concentrates on abstract factors and not concrete individuals. Castel (I99I) argues that populations are monitored in terms of risk: 'A risk does not arise from the presence of a particular precise danger embodied in a concrete individual or group. It is the effect of a combination of abstract "factors" which render more or less probable the occurrence of undesirable modes of behaviour' (Castel, 1991, p. 287). The current interest in health promotion and AIDS surveillance can be seen as examples of this.

The implications of governmentality for the state are immense. If the organisation of welfare can be understood as a technical problem of risk 
avoidance then the nature of state welfare can be radically re-arranged. Assessment and administration become the main if not the only functions of the welfare state. As Castel points out in an era of state welfare contraction 'the interventionist technologies which make it possible to "guide" and "assign" individuals without having to assume their custody could well prove to be a decisive resource' (Castel, 199I, p. 295).

Following this line of argument it could be argued that old age is being treated in this technical fashion. While the state pension is extremely important for the majority of older people in retirement in the UK, whether this is likely to remain so is debateable. In Britain it would seem that pensions policy is focused upon the growing numbers with occupational or private pensions leaving the state pension as a concern only of a minority. The abolition of SERPS and the failure of pensions to keep pace with the rise in earnings are just two indicators of purposeful future trends. The justification that universal pensions 'waste' money on those who don't need it is a way of promoting the policy as being concerned with social justice for the needy. Targeting those who are in greatest need is therefore a technical solution which promotes individuality and, arguably, provides better resources for those in need. This does not mean that resources are not being allocated to older people, they are, but not as part of a universalist welfare programme. Older people benefit in different ways depending on their status and their resources. A further advantage of such a policy is the separating out of a group of older people as primarily welfare benefit recipients among a population of self-supporting self-reliant older people. In this way the ideal of the citizen as consumer relates to both the discourse of modern life and to individual reality.

The relevance of governmentality to healthcare and citizenship is also apparent. In healthcare older people are presented with two images; one is physically frail and dependent while the other is active and healthy - a third ager. Ironically the new rights of citizenship provided by the reforms to health and social services relate to the first while only being meaningful to the second. The ability to exercise choice depends on there being an active consumer who is able to make informed and real decisions. Frailty and dependency are not ideal circumstances from which to exercise consumer sovereignty. Power imbalances and real physical limitations are just two impediments.

This conundrum illustrates the contradictory nature of this new mode of citizenship. Citizens are encouraged to take greater personal responsibility for their health and for extending the period of their third age. However, as those who move into a fourth age of needing health 


\section{$54^{8}$ Paul Higgs}

and welfare services discover, at this point they are transformed from consumers into objects of consumption. The 'medical gaze' which becomes almost statutory at the age of 75 observes, investigates and regulates older people. The surveying state is at its height. Commitments to individuality made in the Patient's Charter are unlikely to overcome the fact that on an acute medical or surgical ward the old person's body is little more than an object of healthcare discourse:

Old people are hurried in and out, their physical and social status assessed and their frailties noted and attended to as efficiently as possible within the law: or they lie, waiting to be claimed by some citizen consumer, aka. carer, where the health service can discharge its responsibilities... And yet, ironically at the point when the body becomes the defining element in a person's life, the health care professionals re-orientate themselves. They construct disembodied packages of care in which the fourth ager becomes a series of categories of response; a new cultural text of met and unmet need (Gilleard and Higgs, 1994, p. I 7-18).

Consumer citizenship for older people depends to a great extent on their resources and health. They are continually being surveyed, but the risks have not yet mounted up to demand intervention. The rolling back of the monolithic and bureaucratic welfare state is not primarily about offering choice and freedom from the 'nanny state'; rather it is about acknowledging that the state doesn't have to get involved in providing responses to risk - it only needs to identify them.

Hence the creation of a targeted or eligible group of older people who have been designated as at risk. These form a sub-class of consumers unable to exercise choice even though they are the only ones eligible to receive services paid for or organised by the state. This provides the modern meaning of citizenship because the only way, it seems, fully to appreciate the fruits of citizenship is to move into the fourth age. This being the case it is not accidental that active seniors have purposefully to separate themselves from, but live in fear of, the fourth age. Their role as citizens is comfortable as long as it is only about their procedural rights - the substantive rights of social citizenship on the other hand are something to be apprehensive about. This may be the case why acute health care is very much a political issue and long-term institutional and community care isn't.

In these circumstances the likelihood of a politics of old age developing are small. The idea that older people will be able to utilise their position as consumers is as naive in these circumstances as it has always been in every other situation. The modern citizen is there to be monitored for 'risk' not to be active. Denial of old age by older people themselves is already more advanced as a strategy and will continue to 
be so. The alienation of old people is therefore a more likely outcome of this latest stage of modernity than their liberation.

\section{Conclusion}

What are the implications of all of this for social gerontology? First, there is the need to question the hegemony of structured dependency theory and of the social democratic vision that goes with it. The idea that social gerontology can provide a theory to explain the situation of older people is important; that such a theory gets attached to a particular strategy is not. This is not to say that the desire to overcome many of the negative features associated with old age should not guide research, but rather that it is necessary to look at how the cultural processes of modern life are changing older people's own understandings of their circumstances. With this in mind abandoning an attachment to citizenship theory might be a good starting point for a more reflexive approach to old age in modern societies.

\section{References}

Arber, S. and Evandrou, M. 1993. Mapping the territory. In Arber, S. and Evandrou, M. (eds) Ageing, Independence and the Lifecourse. Jessica Kingsley, London.

Arber, S. and Ginn, J. I99I. The invisibility of age: gender and class in later life. Sociological Review 36 (I), 33-47.

Bocock, R. I 993 . Consumption. Routledge, London.

Bornat, J., Phillipson, P. and Ward, S. 1985. A Manifesto for Old Age. Pluto, London.

Castel, R. 199 I. From Dangerousness to Risk. In Burchell, R. (ed). The Foucault Effect. Harvester Wheatsheaf, Hemel Hempstead.

Cronin, J. 1984. Labour and Society in Britain 19r8-79. Batsford, London.

Featherstone, M. and Hepworth, M. I 986. New Lifestyles in Old Age? In Phillipson, C. et al (eds) Dependency and Interdependency in Old Age - Theoretical Perspectives and Policy Alternatives. Croom Helm, Beckenham.

Ferris, J. I985. Citizenship and the Crisis of the Welfare State. In Bean, P. et al (eds), In Defence of Welfare. Tavistock, London.

Franklin, M. 1986. The Decline of Class Voting in Britain: Changes in the basis of Electoral Choice $1964-83$. Clarendon, Oxford.

Foucault, M. 1979. The History of Sexuality, Vol I. Penguin, Harmondsworth.

Foucault, M. 1991. Governmentality. In Burchell R (ed), The Foucault Effect. Harvester Wheatsheaf, Hemel Hempstead.

Gamble, A. I 986 . The political economy of freedom. In Levitas, R. (ed), The Ideology of the New Right. Polity, Cambridge.

Giddens, A. 1985. The Nation-State and Violence. Polity, Cambridge.

Gilleard, C. and Higgs, P. 1994. Cultures of Ageing: Self, Citizenship and the Body. Paper, Division of Geriatric Medicine, St George's Hospital Medical School, London.

Gough, I. 1984. The Crisis of the British Welfare State. International Journal of Health Services. 13, 459-477. 
Green, D. 1983. Reinventing Civil Society. IEA Health and Welfare Unit, London.

Henwood, M. I992. Through a Glass Darkly: Community Care and Older People. Kings Fund, London.

Hewitt, B. I 992. Welfare, Needs and Ideology. Harvester Wheatsheaf, Hemel Hempstead.

Kavanagh, D. I986. Thatcherism and British Politics. OUP, Oxford.

Kymlicka, W. and Norman, W. I 994. Return of the citizen: A survey of recent work on citizenship theory. Ethics, 104, 352-81.

Le Grand, J. 1982. The Strategy of Equality. Allen and Unwin, London.

Leonard, P. I982. Introduction to Phillipson, P. Capitalism and the Construction of Old Age. Macmillan, London.

Lister, R. 1990. Women, economic dependency and citizenship, Joumal of Social Policy 19, 445-68.

Mann, M. 1987. Ruling class strategies and citizenship, Sociology, 21, 339-54.

Marshall, G., Newby, H., Rose, D. and Vogler, C. I 988 . Social Class in Modern Britain. Hutchison, London.

Marshall, T. H. 1992. Citizenship and Social Class. Pluto, London.

Marx, K. 1975. Capital, Vol I. Penguin, Harmondsworth.

Midwinter, E. 1992. Citizenship: From Ageism to Participation. The Carnegie Inquiry into the Third Age. Research Paper no 8, Dunfermline.

Phillipson, C. 1982. Capitalism and the Construction of Old Age. Macmillan, London.

Plant, R. I988. Citizenship, Rights and Socialism. Fabian Society Pamphlet no $53 \mathbf{I}$.

Taylor Gooby, P. I 99 I a. Social Change, Social Welfare and Social Science. Harvester Wheatsheaf, Hemel Hempstead.

Taylor Gooby, P. I 991 b. Attachment to the welfare state. In Jowell, R. et al (eds), British Social Attitudes - The 8th Report. Dartmouth, Basingstoke.

Thomson, D. 1989. The welfare state and generation conflict. In Johnson, P. et al (eds), Workers Versus Pensioners. Manchester University Press, Manchester.

Titmuss, R. 1974. Commitment to Welfare. George Allen and Unwin, London.

Townsend, P. 198r. The structured dependency of the elderly: A creation of social policy in the 2oth century. Ageing and Society, $1,5^{-28}$.

Turner, B. 1988. Status. Open University, Milton Keynes.

Turner, B. 1989. Ageing, status politics and social theory. British Journal of Sociology, 40, 588-606.

Turner, B. I990. Outline of a theory of citizenship. Sociology, 24, I89-2 1 7.

Walker, A. and Phillipson, C. 1986. Introduction. In Walker, A. and Phillipson, C. (eds), Ageing and Social Policy: A Critical Assessment. Gower, Aldershot.

Wilson, G. I993. Money and independence in old age. In Arber, S. and Evandrou, $M$. (eds), Ageing, Independence and the Lifecourse. Jessica Kingsley, London. 